\title{
LOVING GOD... UnTO DEATH: The WITNESS OF THE EARLY CHRISTIANS
}

Author:

Sergio Rosell ${ }^{1,2}$

\section{Affiliations:}

'Seminario Evangélico,

Unido de Teología, Spain

${ }^{2}$ Department of New

Testament Studies,

University of Pretoria,

South Africa

\section{Correspondence to:}

Andries van Aarde

email:

andries.vanaarde@up.ac.za

\section{Postal address:}

Faculty of Theology,

University of Pretoria,

Lynnwood Road 0083

Hatfield, South Africa

\section{Keywords:}

martyrdom; suffering;

identity; Paul; love

\section{Dates:}

Received: 06 July 2009

Accepted: 01 Oct. 2009

Published: 19 July 2010

How to cite this article: Rosell, S., 2010, 'Loving God... unto death: The witness of the early Christians', HTS Teologiese Studies/Theological Studies 66(1), Art. \#301, 9 pages. DOI: 10.4102/hts.v66i1.301

This article is available at:

http: / /www.hts.org.za

\section{Note:}

Dr Sergio Rosell

participates as a Research Associate in the research project 'Biblical Theology and Hermeneutics', under the direction of Prof. Dr Andries G. van Aarde, Honorary Professor of the Faculty of Theology at the University of Pretoria, South Africa.

(C) 2010. The Authors. Licensee: OpenJournals Publishing. This work is licensed under the Creative Commons Attribution License.

\section{ABSTRACT}

The article focuses on the social and theological dynamics that drove early Christ-followers to understand martyrdom as being a legitimate and honourable way by means of which to demonstrate love for God to the uttermost limits. Martyrdom is rooted much earlier in the Jewish tradition, though it received new impetus from the second century AD onwards. The study seeks to trace its raison d'être within the pages of the New Testament, both in the sayings of Jesus and the letters of Paul. It is argued that the apostle's theology of suffering provided sufficient grounds for such an understanding, which finds in Ignatius, Bishop of Antioch, one of its major representatives. Finally, the study seeks to reflect on the plausible actualisation of non-bloody martyrdom for today's Christian discipleship, if it has any relevance at all.

El Martirio es una gracia y por ello todos debemos estar dispuestos a morir por nuestra fe, aunque no nos conceda el Señor este honor.

(Mons. Óscar Romero)

\section{INTRODUCTION}

Tertullian once said that 'the blood of the Christians is seed' (Apol 50.13). Although such an oft-used phrase has become somewhat of a cliché in religious circles, it contains a profound truth: our love of God to such an ultimate expression is an appropriate response to his sacrificial love on behalf of humanity.

The 'great' commandment in Deuteronomy 6:4 is contextualised within the Shema ('Hear, O Israel: The LORD our God is one LORD'), which is considered as the creed of the Hebrew people, being 'the fundamental truth of Israel's religion' or 'the fundamental duty founded upon it' (Craigie 1976:168; Driver 1902:89). The community is exhorted to love God in a holistic way: 'you shall love the LORD your God with all your heart, and with all your soul, and with all your might' (Dt 6:5). The commandment further expresses the promise of long life granted in 'the land you shall possess' (Dt 5:33), so that their 'days will be prolonged' (Dt 6:2). Such a promise is closely related to both the quality and length of life that results from living according to God's statutes. The gospels later recapture the essence of such a commandment in the words of Jesus. Jesus recites the Shema in response to the question which is asked by an interpreter of the law concerning the greatest of the commandments (Mt 22:33-40). In the Lukan version of such words, Jesus links obedience to the commandment with the promise of (long) life (Lk 10:28): 'You have answered right; do this and you will live' ( answer, since the interpreter of the law wants to know how he may come to inherit eternal life (Lk 10:25:

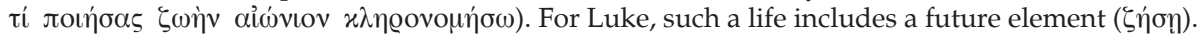

The love for God, then, is closely related to the promise of life. We are not to understand this 'eternal life' in terms of a dualistic scheme, as something that transcends the earthly realm, but as part and parcel of Shalom, which is announced in the pages of the Old Testament. The words signal both a present reality and a future consummation. They embody the 'already but not yet' of Christian life. ' $\zeta \omega \eta$ ' bears to some degree the character of something for which we still hope, and to some degree it is a present possession' (Bultmann 1964:865).

The commandment does not solely focus on the inner being of the individual, but possesses a marked centrifugal element. Jesus combines it with 'love for the neighbour' (Mt 22:39, as the basis for the 'law and the prophets'). The exercise of such a commandment has social implications for life in the here and now. However, at the end of the first century $\mathrm{AD}$ and at the beginning of the second, some understood such love as consisting of a response to God's love in the form of a final and testimonial act, which claimed all from the human subject. Such was a testimonial act in the most literal sense of the word:

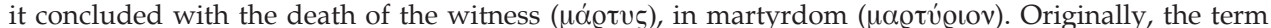

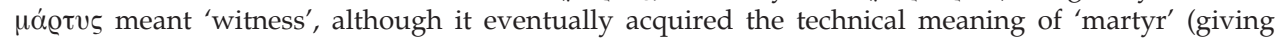
witness to Christ with one's life) with which we are now familiar.

Does such a manner of perceiving Christian discipleship represent a deviation from Jesus' original intention, or is it faithful to his message? It is noteworthy to observe the extremes to which some Christians had fallen by the fourth century. Augustine, responding to the Donatist martyrs, affirmed that to kill oneself - regardless of the circumstances - was a breach of the sixth commandment ("Thou shall not kill') and should be treated as murder (CivD 1.19).

From where does such an understanding receive its stimulus?

\section{ANTECEDENTS OF A THEOLOGY OF MARTYRDOM}

In what follows, we shall briefly comment on the perception that the Old Testament had concerning death and the active search for it. We shall, nevertheless, concentrate more on the New Testament texts and especially on the writings of the apostle Paul. 


\section{The Old Testament}

The theme of death, or the active search for it, is not foreign to the Old Testament, in which we find at least six references to voluntary deaths - Abimelech (Jdg 9:54), Samson (Jdg 16:30), Saul and his squire (1 Sm 31:4-5 = 1 Chr 10:1-7), Ahitophel (2 Sm 17:23), and Zimri (1 Ki 16:18-19). It is clear that all such cases cannot be considered under the rubric of 'martyrdom', as we understand such a term today. For some, voluntary death was preferred to falling at the hands of the enemy and thus suffer dishonour (such as occurred in the case of Saul) Others ended their lives by their own hands after having been wounded by a woman (such as Abimelech), with resultant lossof-face in front of the community. In the case of Ahitophel and Zimri, the text comments on the manner of their death, without offering any further explanation for it. The death of Samson is presented as a positive act of self-sacrifice, with which God involves himself. Tabor (1992:575) considers such a passage to be 'proto-martyriological'. The suffering servant of Isaiah 40 to 55 , who consciously walks to his death as a vicarious act, is the highest example of sacrificial offering and a paradigm for New Testament times.

One more text in the book of Daniel needs to be commented on. Placed within the context of the Babylonian exile, the text in question refers to the persecution of the Jewish people under Antiochus Epiphanes in $c$. BC 167. Subject to impending affliction, the text implies that many would choose death rather than forsake the faith of the fathers. The narrative of the three young men in the fiery furnace might have functioned as an example for, and encouragement of, such a generation. The practice of preferring death rather than transgressing God's law also accompanies later extra-canonical literature, namely the Maccabean corpus (in which we find the terrible tale of the seven brothers skinned alive before their mother; cf. 2 Macc 7:2), as well as the apocryphal Testament of Moses, etc.

It is no wonder, then, that the period under discussion displays a rich development of the concept of the vindication of the righteous, the universal judgment and life after death (Tabor 1992:575). The New Testament shares such a frame of mind. In Hebrews 11, the Hall of Fame of the heroes of the faith accommodates those who 'were tortured, refusing to accept release, that they might rise again to a better life' (Heb 11:35).

\section{Extra-biblical sources}

Josephus is our best source at this point. Both Antiquitates Judaicae and Bellum Judaicum contain more than twenty-five incidents of heroic deaths occurring in the face of an otherwise shameful fate of dying at the hands of the enemy. The best-known such case took place at Masada, where more than 900 men and women voluntarily ended their lives rather than surrendering to the Roman armies (BJ 7.320-406), according to Josephus.

Rabbinic literature abounds on the topic, suggesting that the individual must refrain from looking for a way out of peril when fidelity to the Torah is in view (cf. b. Aban Zar 18a-18b). The underlying concept of such texts is that God alone has the power over life and death, not the individual (Tabor 1992:578). Schneider (1967) comments:

The Jewish religion is a religion of martyrdom. It is born out of martyrdom and the sufferings of the righteous in the Maccabean age. At the end of our epoch stands the figure of the martyr Akiba, who rejoices because in his martyrdom he first fulfils in truth the saying: 'Thou shalt love your God with thy whole soul.'

(Schneider 1967:486)

We have to take care that we do not deduce from such a statement that the early Christian concepts were borrowed directly from the Maccabean tradition.

The figure of the prophet who for the sake of his mission, or the righteous man who for the sake of his piety, suffers calumny, persecution and even death, was known to Israel prior to the time of the Maccabees.

(Schneider 1967:486)
Accordingly, the person of the prophet who dies develops into a topos in New Testament literature (cf. Mt 23:37; Lk 13:13, etc.). However, the use of i $\lambda \alpha \sigma \tau$ inoเov in 4 Maccabees 17:21 has the effect of expiating/propitiating God, which results in the downfall of Antiochus and the liberation of the people. Such a concept is closer in meaning to Romans 3:25 than is the prophetic reference that we have mentioned, which is rooted in the Greek tradition.

\section{The witness of the New Testament}

The apostle Paul, in one of his more condensed theological letters, writes to the Christ-followers in Rome that they now enjoy peace with God through Jesus the Messiah. Paul exhorts them to stand firm in the face of adversity, since it is but a springboard to their Christlike maturity:

More than that, we rejoice in our sufferings, knowing that suffering produces endurance, and endurance produces character and character produces hope, and hope does not disappoint us, because God's love has been poured into our hearts through the Holy Spirit which has been given to us. While we were still weak, at the right time Christ died for the ungodly. Why, one will hardly die for a righteous man - though perhaps for a good man one will dare even to die. But God shows his love for us in that while we were yet sinners Christ died for us.

(Rm 5:3-8)

Paul emphasises Christ's unselfish gift of himself, which he gave even on behalf of his enemies ( $\operatorname{Rm} 5: 10)$. As if wishing to take his argument a step further, Paul affirms that a voluntary death that is suffered on behalf of the community is not something novel but should be thought of as a possibility: why one should hardly die for a righteous man, though perhaps, for a good man, one might dare even to die.

To die for a good person or for a just cause is something quite different from dying on behalf of those who are enemies. The Romans were already acquainted with some eastern tribes where people would kill themselves as a sign of social protest. In contrast, the example of Christ defied all logic. Such a death was thought to be scandalous, and brought the apostle the widespread rejection of those whom he aspired to reach with the good news of Christ, outwitting any apprehension of the 'foolishness of the cross' (1 Cor 1:23, 25).

The gospel of John implies that Jesus might have hinted at what it meant to follow him during his earthly ministry. In the epilogue of the said gospel, we find the well-known scene in which Jesus confirms Peter after the latter has betrayed the Lord Earlier, Peter had wanted to follow the Master, without counting the cost:

Simon Peter said to him, 'Lord, where are you going?' Jesus answered, 'Where I am going you cannot follow me now; but you shall follow afterward.' Peter said to him, 'Lord, why cannot I follow you now? I will lay down my life for you.' Jesus answered, 'Will you lay down your life for me? Truly, truly, I say to you, the cock will not crow, till you have denied me three times.'

The disciple clearly links following Jesus with making a sacrifice. By this time, the disciples had enough insight to arrive at such a distinctive conclusion. ${ }^{1}$ Before his final entrance into Jerusalem, Jesus is anointed in an act that anticipates his death, to which John refers by the use of a softer term, burial (Jn 12:7). After the scene under discussion, there follow a series of statements in which Jesus announces his death at the hands of the local authorities. Speaking of it as the 'moment of his glorification' and his 'hour', the reference becomes a theological topos.

1.In the gospel of John, Jesus, informed about the death of his good friend Lazarus, waits for two days before travelling to Bethany (Jn 11:6), aware that the Jews plot to kill him (11:8). Jesus' intention is firm, and provokes the adoption of a bold attitude on the part of a disciple (Thomas), who, nevertheless, will later on in the narrative express doubt about Jus' resurrection (Jn 20:27): 'Thomas, called the Twin, said to his fellow to his fellow disciples, 'Let us also go, that we may dith ( included encountering impending danger, of which the early Christ-following communities were, no doubt, aware. 
Returning to the passage mentioned earlier, John 21:15-19 appears to convey the idea that Peter's last days will indicate his uncompromised identification with the divine plan:

'Truly, truly, I say to you, when you were young, you girded yourself and walked where you would; but when you are old, you will stretch out your hands, and another will gird you and carry you where you do not wish to go.' (This he said to show by what death he was to glorify God.) And after this he said to him, 'Follow me.'

(Jn 21:18-19)

As Castillo (1998:68, author's translation) observes: 'Jesus invites the person to come out of oneself, to forget about oneself in order to be completely open to the destiny which Jesus traces for the person.' The creation of such an opening has direct relevance to human relationships, which are built in the here and now, rather than conveying a sense of mortification of the flesh, or the sense of an ascetic exercise.

What is clear in the gospels is that Jesus suffered on the cross not as a kind of personal mortification, but as the direct result of a life that needed to end in such a way in order to provide conclusive evidence of a man who spoke and practised the truth. The cross was the ultimate result of the lifestyle that he chose for himself (Castillo 1998:113).

Such a love for God, as endured to its uttermost end, was to become the paradigm of the faithful disciple. In the narration of Stephen's stoning in Acts 7, the martyr plays an incipient role, announcing the extension of God's promises beyond ethnic boundaries. His death is presented as being in line with the model that we find of the death of Jesus in the gospel of Luke:

${ }^{34}$ And Jesus said, 'Father, forgive them; for they know not what they do.' And they cast lots to divide his garments... ${ }^{46}$ Then Jesus, crying with a loud voice, said, 'Father, into thy hands I commit my spirit!' And having said this he breathed his last.

(Luke 23:34, 46)

${ }^{55} \mathrm{But}$ he, full of the Holy Spirit, gazed into heaven and saw the glory of God, and Jesus standing at the right hand of God... ${ }^{59} \mathrm{And}$ as they were stoning Stephen, he prayed, 'Lord Jesus, receive my spirit. ${ }^{60}$ And he knelt down and cried with a loud voice, 'Lord, do not hold this sin against them.' And when he had said this, he fell asleep.

(Acts 7:55, 59-60)

In popular hagiography, Jesus' meek death was taken as a literary pattern, which deeply affected people's sensibilities. His example was regarded as a leading motivation for the early disciples, especially in the light of the rejection that they suffered for their alliance with the crucified Lord. Later on in Acts 22:20,

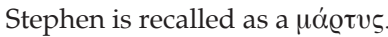

Martyrdom was, no doubt, a real possibility during the first decades of the early Christ-following community. Several texts (Mt 10:24; Lk 21:12-16; In 16:1-4; 15:20) describe persecution as a way of being. After the description of the death of James in Acts 12:2, Paul's life is used to provide evidence of a similar experience (Lystra, Ac 14:8-23). The apostle shares his sufferings, which verges on the experience of martyrdom, with his communities on several occasions (Rm 8:35; 1 Cor 4:10-13a; 2 Cor 4:8-9; 6:4b5, 8-10; 11:23b-29; 12:10; Phlp 4:12). On at least eight different occasions, Paul speaks of the difficult circumstances that 'either have imperilled or threaten to imperil his apostolate and the faith of Christian churches' (Hodgson 1983:63). Such lists of experiences (Peristasenkatalog) were common in the ancient world and have been studied in reference to the Stoics and the tradition of self-mastery, as tests of the character of a wise man (Hodgson 1983:59-60; Malherbe 1968:72).

\section{Suffering in Paul's letters}

As revealed in Acts, Paul suffered on many different occasions. Coupled with the stress of his long and perilous journeys, he was also subjected to rejection wherever he stayed, whether at the hands of angry local mobs (Ac 16:19-21, 19:21-41) or as the direct result of Jewish opposition (Ac 13:45; 14:1-2, 19; 17:5, etc.). Such repeated experiences marked the way in which Paul came to understand how God intended his life to be.

Near-death experiences permeated Paul's theology. On one occasion, Paul refers to such an experience, which he shared with some of his brethren in the faith, in clear eschatological terms:

Who shall separate us from the love of Christ? Shall tribulation, or distress, or persecution, or famine, or nakedness, or peril, or sword? As it is written, 'For thy sake we are being killed all the day long; we are regarded as sheep to be slaughtered.

(Rm 8:35-36)

Wilckens (1992:216) observes that Christians are willing to suffer with Christ in order to be glorified together with him ( $\mathrm{Rm} 8: 17 \mathrm{c})$. It is for this reason that, amid their present suffering, they are, nevertheless, able to experience victory. By concentrating on the apostle Paul, we are able to focus on the sacrificial example of Jesus, who, more than anyone else, has influenced how the phenomenon of suffering might be identified with the vision of God in Christ.

Situating Paul in his proper social milieu is of key importance to the development of the argument in the present text. Bloomquist (2007:270-271) describes the first-century Mediterranean world as pessimistic, since death (and suffering) are ever-present realities that place a heavy burden on the individual and society. Drawing on the work of Dodds, Bloomquist places Paul as existing within such a general frame of mind. Paul presents suffering and death as concrete realities, although such a presentation does not necessarily presuppose a general pessimistic outlook in life, as Bloomquist contends.

Bultmann (1910) understood such suffering lists as sprouting from the Hellenistic philosophical influence that found its parallel in Epictetus (Diss 2.10.17; 19.24), among others. 'For Epictetus the $\pi \varepsilon \varrho \iota \sigma \tau \alpha \dot{\sigma \varepsilon \varepsilon \varsigma \zeta ~ o r ~ ' a d v e r s e ~ c i r c u m s t a n c e ' ~ r e p r e s e n t e d ~}$ those obstacles to a dispassionate life to whose hurdling the Stoic gradually trained himself. The Stoic's ability to bear hardship

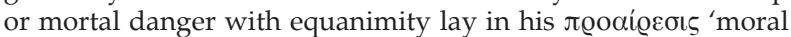
purpose' (Hodgson 1983:68). However, Paul clearly confessed to experiencing distress on occasion (cf. 2 Cor 1:8-9: 'For we do not want you to be ignorant, brethren, of the affliction we experienced in Asia; for we were so utterly, unbearably crushed that we despaired of life itself. Why, we felt that we had received the sentence of death; but that was to make us rely not on ourselves but on God who raises the dead.'). However, he attributes the victory over such circumstances to the power of God, rather than to 'self-mastery' (2 Cor 12:9-10). Such a concept runs counter to Stoic pride, of which a clear example is found in Epictetus: 'Show me a man who though sick is happy, though in danger is happy, though dying is happy, though condemned to exile is happy, though in disrepute is happy. Show him! By the gods, I would fain see a Stoic!' (Diss 2.19.24; in Hodgson 1983:67).

Other lists were provided in popular Graeco-Roman moral and philosophical portraits of the sages and philosophers, as well as of others: Plutarch (Mor 326D-333C; 361E-362A; 1057D-E); Seneca (Ep 85.26-27); Dio Chrysostom (Or 3.3; cf. Hafemann 1993:921; Kruse 1993:19). Fitzgerald (1988:43) argues that, in Graeco-Roman literature, the scars that the good man bears are visible tokens of his virtue (in the grouping together of bonum and virtus, that is, the good man is he who is virtuous).

However, suffering is not a token of virtue for Paul, but is rather

2.In his commentary on 2 Corinthians, Bultmann (1976:231-232) highlights at least the following two distinct elements in Stoic and Pauline thought: (1) In Stoic thought, suffering is not seen as impinging upon the sense of being, whereas for Paul 'man sufering is not seen as imping as man is quallied as a surfering being' and (2) The ability to transcend suffering is at least for the Stoic understanding of a human being's constitution, assured by the right use of the moral purpose, whereas for Paul 'the ability to transcend suffering is

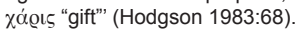


a way of identifying with Jesus Christ. As Hock (1980:60-61) has shown, Paul's way of using such lists resembles that of the typical descriptions of suffering, which were common to artisans in the ancient world. Hock compares Paul's comments on the seeming weakness that his trade awakens in the Corinthian community to the impact of Lucian on the shoemaker Micyllus (Lucian, Cat 1, 14-15, 20, 22; Somn 6-9, 13). As Hock (1980:60) observes, for the

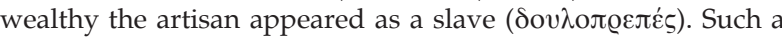
reference is crucial, as can be seen in the letter to the Philippians,

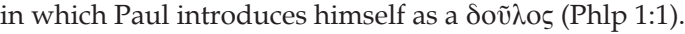

In the lists of suffering in intertestamental literature, some specialists point out, 'not only formal and material parallels to Paul but also [show] that the apocalyptic frame of reference for such lists is more congenial to Paul than the Stoic' (Hodgson 1983:68). The references are numerous: 2 En 66:6; TJos 1:4-7, 2:7; PssSol 16:14-15; 4 Macc 17:11-16; Sir 2:1-5; Wis 3:5-6. Some of the texts display the overlap between Hellenism and Judaism that occurred during Paul's time, which influence (in a more literary than ideological/theological way) had informed the apostle's way of writing. ${ }^{3}$ However, when we come to the crux of both the function and context of such lists, it seems clear that Paul is more influenced by the Old Testament and his Christology (Hafemann 1993:921). The Christological element is central to the understanding of Paul and his theology; it is the natural and concrete outcome of a life devoted to the service of others, which is patterned after that of Jesus the Christ.

'Rather than questioning the legitimacy of his apostleship because of his suffering, Paul considered suffering to be a characteristic mark of his apostolic ministry' (Hafemann 1993:919; see 1 Cor 2:1-5; 2 Cor 11:23-29; Gl 6:17; Phlp 1:30; 2 Tm 1:11-12; 2:9). Hafemann's assessment falls short of the mark. As a matter of fact, the letter to the Philippians is one of the few texts - apart from 1 Thessalonians and 2 Thessalonians - in which Paul does not present himself as an apostle at the opening of the letter. In the well-known passage of Philippians 3:5-11, the suffering topos becomes the means of attaining the closest union that is possible with Christ: 'that I may know him and the power of his resurrection, and may share his sufferings, becoming like him in his death' (RSV). Such identification led some nineteenthcentury scholars to reformulate the theory regarding suffering, which was expounded by Ignatius as consisting of ethical intention (cf. Bloomquist 1993:34). They came to base their theory on those findings that had recently been made regarding Christmysticism, resulting in somewhat extreme claims regarding such a phenomenon. Schmitz (1924:185-187) concluded that both Paul's and Christ's sufferings were as one. However, such identification does not ultimately imply the dissolution of one's identity in Christ, as the individualism of personal identity remains (Campbell 2008:156).

In order that the erroneous impression might not be given that Paul's identification with Christ is solely based on his present sufferings, the focus should be placed on the element of joy that is present in such experience ( $\chi \alpha \varrho \alpha ́)$. The presence of joy can be detected throughout Philippians, as much as suffering is. Holloway (2001:74-75) observes that the apostle mentions $\chi \alpha \varrho \alpha$ and cognates sixteen times in the letter, with $\chi \alpha 0 \alpha$ being used as one of the two consolatory topoi in Philippians (the other being the adiaphora topos, which relates to the distinction between those things that matter and those that do not, as can be seen in Phlp 1:10a). Holloway (2001:101) affirms, citing John Chrysostom's commentary on Philippians (Ep ad Phil, praef. 1), that suffering and joy are two sides of the same coin: 'In the beginning of his

\footnotetext{
3.For further examples of such an overlap, see Josephus, BJ 2.8.10; IV.3.10; Ant 3.2.2; I.6.6. Also see the Mishnah (M.B. Qam. 1:1; M. Pe'ah 2:7; M. Šabb. 2:5), which accords with the common Jewish notion that all suffering is part of death (cf Cor 15.31: Hafemann 1993.919). The Coptic texts of Nag Hammadi (AcPtTwAp VI, Cor 15.31, Hatema 10. 1, 5, 20-30; Grow $V 1,4,39,126-130$, etc., from the second and fourth centures (the world which can be read as reverting back, at least to a certain extent, to the first century AD. For examples of such thinking, see Hodgson (1983:72-75)
}

letter Paul offers the Philippians much consolation regarding his imprisonment, showing not only that they should not be troubled, but that they should rejoice.'

Due consideration must be given to how such comprehension of suffering affected the identity of early Christian communities, in terms of whether they rejected, modified or applied it as is.

\section{LOVING GOD ... UNTO DEATH: THE WITNESS OF CHRISTIANS DURING THE SECOND TO FOURTH CENTURIES}

Considering how personal experiences shape a person's theology differs from assessing how, decades later, that same ideology had taken root in different communities. The tragic fate of Jesus, which served as the reason behind the movement, no doubt left an indelible mark on his followers. In the middle of the second century AD, the author of Martyrdom of Polycarp had to exhort Christians to refrain from voluntarily handing themselves over to the local authorities in order to be martyred (MartPol 4). What had taken place, and what the conditions were that called for such drastic measures, has to be considered.

\section{A society prone to the desire for death}

E.R. Dodds, who studied the pagan-Christian dialogue in the first centuries $\mathrm{AD}$, commented that in a period when earthly life was increasingly devalued and guilt-feelings were widely prevalent, Christianity held out to the disinherited the conditional promise of a better inheritance in another world' (Dodds 1965:135). Despite those attacks by the pagans that served to affirm that Christianity appealed only to 'weak souls' (Porphyry, Christ 87), there was a generalised conscious desire to seek death (as expressed by Seneca in the first century AD in Ep 24.25: affectus qui multos occupavit, libido moriendi). ${ }^{4}$ Dodds discerns the reasons for such general anxiety during the third and fourth centuries as being: the lack of a proper interpretation of current events, the lack of a proper explanation of the position of the individual in the universe, the lack of a spirit of vitality, in comparison with the Christian spirit and especially, the lack of direct support by the state which might else have soothed the fears and needs of its citizens.

Other elements also strongly impacted the psyche of the population (Stark 1997:155), of which one was the high rate of mortality. ${ }^{5}$ The Roman Empire suffered two widespread epidemics, which impacted on a major portion of the population. During the reign of Marcus Aurelius, around AD 165, a smallpox epidemic affected more than a quarter of the population of the time, as well as causing his death. In AD 251, a measles epidemic caused widespread havoc throughout the Empire. Although it is difficult to estimate the total death toll, at the height of the epidemic at least 5000 people died daily in Rome alone (Stark 1997:77).

How Christians generally behaved during such times contrasted markedly with the means of self-preservation for which most pagans opted. Lohfink (1998) comments on the contrast. Whereas the healthy and some of the 'best' of the Christians were dying, as they cared for their sick, the pagans regarded the 'proper' action to be taken as consisting of their fleeing from the affected areas. The written evidence to support such a finding consists of scarce extant literature emanating from Christian authors (see also Sanders 2000:172 in this regard). Stark (1997:82-83) offers

4.Porphyry himself contemplated committing suicide after a period of severe illness Lucian (Peregr 13) says that 'the majority of them (i.e. the Christians, SR) handed themselves over voluntarily'. Celsum (as reflected in Origen, Cels 8.65) agrees with such a sentiment. Clement of Alexandria, (Str IV 17.1) comments about those who

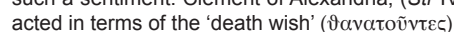

5.Brown (1993:22) believes that the average age at death in the Roman Empire during the second century AD was below 25 years, whereas Lenski and Lenski (1987:179) consider it to have been between 35 and 40 . 
the letters of Cyprian and Dionysius that reflect such conduct, though their witness was late. What we do know is that the social concern of Christian communities eventually threatened the existence of the Roman Empire, since they came to draw much support and to earn the trust of the people. A century later, the emperor Julian tried to combat the prevalence of the 'Galileans' by encouraging the pagans to match the virtues of such 'despicable subjects' by means of instituting stateorganised charities (Stark 1997:83-84). We know of unnamed Christians who well-understood the social cost of living a life devoted to the care of others. Dodds' assessment, which went unchallenged for some time, was that the spirit of paganism at the time was weary, having lost faith both in science and in itself: 'Christianity, on the other hand, was judged to be worth living for because it was seen to be worth dying for' (1965:132).

However, Dodds' judgement is based on a selective reading of the sources, inspired - no doubt - by his 'confident' view on the Christian movement (Clark 2004:13-15). Paganism seemed to be vibrant in the third century AD, rather than the decaying corpus that Dodds imagined. Whether such a modification of the 'benevolent' traditional view presents an insurmountable obstacle to our argument is debatable. It need not, because rather than emphasising a single element (confrontation namely, Christianity versus paganism), the Christian movement is studied as one of a number of variegated religious options in Roman society (cf. Sanders 2000:9). Having said that, it is only fair to observe that Christianity was the one option which was not compatible with traditional religion, since its followers were expected to refuse to make sacrifices to, and acknowledge, the gods of Rome. It was, then, logical to expect some sort of social pressure to be applied to conform to traditional mores (cf. Rives 1999:135-154).

\section{Suffering and martyrdom}

Although suffering and martyrdom are not necessarily the most outstanding characteristics of Christian identity, they are important ones in early Christian experience. ${ }^{7}$ Castelli, who undertook the study of martyrdom in terms of memory theory, argues that 'martyrologies suture the present (and the future) to the past' (2004:30). Cobb defends a similar idea: 'The martyrologies reflect Christian culture, to be sure, but they are also integral to its construction' (2008:5).

Readiness to suffer for the Name is understood both in Paul and Polycarp (the latter of whom wrote to the Philippian Christ-following community six decades later) as fulfilling the principle of 'not looking after one's own interest'. Such an active

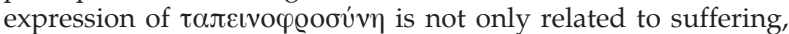
but also to service and self-giving on behalf of others (cf. Phlp 2:21-22; Ep 8.1). However, such qualified suffering is impelled by what, in my opinion, amounts to a Pauline reflection on Christ's descent, as it is found in the Christ-hymn (Phlp 2:6-11). The perception of such an impetus permeates the entire New Testament, ultimately harkening back to Jesus' words (cf. Jn 12:24-25; Mt 10:21, 38 and par).

The two concepts of mysticism and martyrdom are intimately related in Ignatius, who is heavily influenced by the apostle Paul. Ignatius, in turn, influenced the younger Polycarp, when the Bishop of Antioch visited him on the way to his martyrdom. In the former's case, it is not his theoretical discussion of martyrdom, but his own personal acquaintance with suffering

6.Roman sources generally disapproved of the Christians' attitude to death (see Marcus Aurelius, Meditations 11.3). Galen, court doctor to Marcus Aurelius, is the only Roman source who writes somewhat favourably of the Christian attitude to death (cf. Clark 2004:44; Wilken 2003:79-80).

7.A recent work, Dying to be Men (Cobb 2008), affirms that an emphasis on suffering did not actually help the Christian agenda, since the martyrologies depicted the Christians as being oblivious to pain. Christians ultimately aimed at perfecting Roman virtues (Ibid, 62) I would like to distinguish between a general ing Roman virtues (Ibid., 62). I would like to distinguish between a general idea of suffering, which is the outcome of faithfulness to the gospel, and the martyr's capacity to endure pain at the time of death. As I mentioned earlier, at least in the case of Paul, endurance to suffering is found in Christ's sphere (Phlp 4:13), rather than in Stoic-like self-mastery. (as informed by Paul) that drives him to identify more closely with God (ëvwors or 'union'; cf. Ayán Calvo 1991:87-88). For him, martyrdom, which is based in the passion of Jesus, and therefore provides the closest link with Christ, affects three areas: solidarity with, and the pursuit (Rm 6.1), and imitatio of, the passio Christi (Smy 4.2).

Martyrdom is not, for the Antiochean Bishop, a mere characteristic of a close union with Christ; it is also a sign both to the world in general ( $R m$ 3.2-3) and, more specifically, to those heretics who followed the Gnostic/docetic teachings ( $R m$ 6.1). Such signification is due to its implying a witness in favour of the authentic faith in the form of the incarnation and passion of Christ (Ayán Calvo 1991:89). Ignatius, being fearful that, in his visit to the churches on the way to his martyrdom, he might be urged by good-willed Christians to seek a way out of his situation ( $R m$ 7.2), exhorted them in the following way:

Pardon me, brethren: do not hinder me from living, do not wish to keep me in a state of death; and while I desire to belong to God, do not ye give me over to the world. Suffer me to obtain pure light: when I have gone thither, I shall indeed be a man of God.

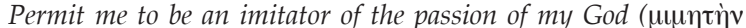

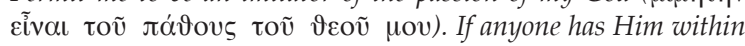
himself, let him consider what I desire, and let him have sympathy

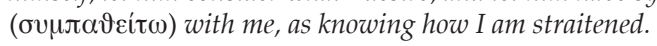

( $R m$ 6.2-3)

It seems as though martyrdom would indeed, in Ignatius' theology, complete a real Christian anthropology in imitatio Christi fashion. Later on, Clement of Alexandria (c. AD 150-215) would write in the polemic context of his Stromata that the ultimate reason for martyrdom is both the love for God and for the neighbour' (Str VII 42-55). Martyrdom is regarded as the most authentic manifestation of the perfect human being, since it is the 'perfect work of love' ( Merino Rodríguez 2003:15-16).

Martyrdom functions as a powerful emotional 'reinforcement' for the group as a whole. Polycarp's remains, after he had been burned at the stake, were retrieved by his followers. MartPol continues:

And so afterwards we took up his bones, which are more valuable than precious stones and finer than refined gold, and laid them in a suitable place; where the Lord will permit us to gather together, as we are able, in gladness and joy and to celebrate the birthday of his martyrdom for the commemoration of those that have already fought in the contest, and for the training and preparation of those that shall do so thereafter.

(MartPol 18.2-3)

Such a statement recalls what Polycarp had to say about Ignatius and his companions when they visited the church in Smyrna on their way to Rome (cf. Ep 1.1: he saw them as 'images of true love', bearing their chains as though they were 'saintly bonds' and 'diadems'). Such an epiphany served to reinforce the identity of the group that Polycarp led, conferring boldness on it. We know that the martyrs received special honours, with their remains being placed in special commemorative shrines (Droge \& Tabor 1992), which later became loci of pilgrimage and festivals.

Stark's (1997) study focuses on the sociological dynamics that served to reinforce the holding of such an attitude by the ingroup towards what appeared to be a wilful renunciation of an individual's most precious element (namely life), against all logic. Paul's reflection on the suffering of Christ had a profound impact on the churches in these early centuries (Glancy 2006:99135). The theme of imitation, which is so prevalent throughout Philippians, returns once more to centre stage in relation to such a period. Such imitation consists of suffering lived in joy, although, for some, such imitation is only a symptom of the anxiety that prevailed in the epoch in which they lived. Such anxiety was based on fear of the irrational, being seen as a form of 'deviancy' (cf. Thompson 2002:27-52). Riddle comments:

8.The date of Polycarp's death is the date of birth to eternal life (Ignatius, $R m$ 6.1, 'The pangs of a new birth are upon me'; Ayán Calvo 1991:269). 
One of the elements of the morbid desire for martyrdom was the abnormal enjoyment of the pain which it involved ... Clearly, the voluntary surrender of one's self to the experience of martyrdom, when it was known that the most exquisite tortures were involved is prima facie evidence of the presence of the tendency towards masochism.

(Riddle 1931:64)

Starting with his own prejudices and antagonism towards any religious manifestation, as if they were solely based on the irrational, Riddle is unable properly to justify the making of such a statement. His views represent a 'pessimistic reading' of the sources involved (cf. Clark 2004:44-45). In contrast, for Stark, the sacrificial element in the Christian religion consists of responding to a rational choice, as 'sacrifice and stigma were the dynamo behind the rise of Christianity' (Stark 1997:167).

Using an 'economical approach' (which takes into account rewards, losses, and the counting of cost), Stark defends the fact that religious adherence, including even self-sacrifice, is not based upon the irrational, as some (especially the Chicago School) had concluded. ${ }^{9}$ Such an opinion concurs with what we observed in Paul. His lifestyle was not 'a compulsion laid on him from the beginning, but a deliberate choice' (Wengst 1988:46-47). Observe, for example, Paul's rational logic in Phlp 1:21-26. Stark presents an interesting element in his study of the experience of conversion. Drawing from such contemporary religious movements as the Moonies and the Mormons, he concludes that conversion is not about 'seeking or embracing an ideology; it is about bringing one's religious behaviour into alignment with that of one's friends and family members' (Stark 1997:16-17). Accordingly, within the small group of Christfollowers, we might perhaps expect strong familiar bonds that serve to reinforce the overall conduct of the in-group. Certainly then, the Christ-phronesis that Philippians 2:5 proposes is not merely an ideological programme, but a way of living out the common faith, based on the experience of renouncing selfinterest on behalf of seeking out the good of the group, and even of a society that is hostile to such a lifestyle. For Paul, the clearest example of such behaviour was that of Christ (Phlp 2:6-11), who did not shy away from presenting his own life as paradigmatic (Phlp 3:17). It could be that, by the end of the first century AD, suffering (namely martyrdom) had started to become one of the strongest reinforcements of such a life-orientation. ${ }^{10}$

Nock believes that the acts of martyrdom, in opposition to embodying a socially dominant principle, become the Christian type that the pagan citizens can recognise:

Law has been defined as the interference of the State in the actions and passions of humanity. The martyr is the man who resists this interference, who claims that his resistance is based on other and higher sanctions, and who will not concede a point even if compliance would save him from the consequences of his previous disobedience. Often he welcomes the opportunity of bearing witness to the faith which is in him.

$(\text { Nock 1933:193) })^{11}$

9.Stark (1997) applies what is called rational choice theory. The presupposition of the theory is that religion provides compensation in place of the desired rewards, which are either scarce or unavailable (35-36). Compensators are the means of arriving a such a reward. Thus, the promise of eternal life points to something beyond earthly existence, and supposes a deep desire for immortality, which is common to most people (168). Religious compensators are beyond the possibility of evaluation, and are inherently risky (implying, in the case of Christianity, faith, Jiotıs, which is the lowest grade of cognition, being the state of mind of the uneducated, according to Graeco-Roman belief, as can be seen in Cels 1.9. cf. Lane Fox 1987:31; Wilken 2003:77).

10. Traditional Romans were repelled by the Christian insistence on death and the dead, although death had a place in common parlance. Philosophers offered advice on coping with pain and death, which was to be brought into perspective by reason. Later Christians were accused of rejecting reason by demanding faith beyond reasonable grounds. It is, therefore, important to take Paul's reasoning into account to balance such a nuanced perspective (cf. Clark 2004:46-47)

11.It is obvious that the image of the martyr presents an extraordinary mental and before created the type of wisdom and virtue that heroically opposes the status quo, which can, in fact, inflict death on the individual, but which does not have last word (Nock 1933:196). In Christian circles, the martyrs were thought to provide early evidence of the resurrection (Clark 2004:54)
It is not strange that the type-symbol becomes the model to imitate, sometimes leading to incredible excesses. Clement of Alexandria, as mentioned earlier, provides extensive coverage of martyrdom in the fourth book of his Stromata. Clement praises the way of the martyr, as it embodies the unflinching desire to follow the Lord, and martyrdom as a unique way open to all (i.e. men and women, slaves and free, Str IV 8; IV 118.1). However, he is concerned about the abuse of such a phenomenon:

Now some of the heretics who have misunderstood the Lord, have at once an impious and cowardly love of life; saying that the true martyrdom is the knowledge of the only true God (which we also admit), and that the man is a self-murderer and a suicide who makes confession by death; and adducing other similar sophisms of cowardice. To these we shall reply at the proper time; for they differ with us in regard to first principles. Now we, too, say that those who have rushed on death (for there are some, not belonging to us, but sharing the name merely, who are in haste to give themselves up, the poor wretches dying through hatred to the Creator) these, we say, banish themselves without being martyrs, even though they are punished publicly. For they do not preserve the

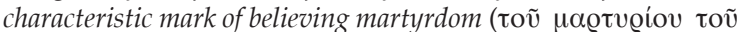

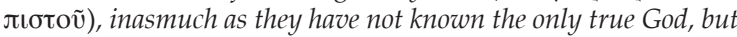
give themselves up to a vain death, as the Gymnosophists of the Indians to useless fire.

(Str IV 16.3-17.4)

Clement does not shy away from martyrdom as though it were a practice against one's own body or God's law. He merely ascribes martyrdom its proper place, so that it will be carried out according to the gospel (which Polycarp had earlier affirmed - such martyrdom is 'according to the gospel': tò

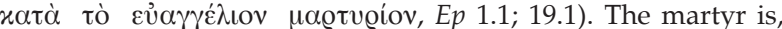
thus, for Clement the gnostic, who is characterised by a 'holy indifference', being a person who has arrived at a (secret) perfection and who is oblivious to the values of the world (Rodríguez 2003:15). Martyrdom is the 'perfect work of love'

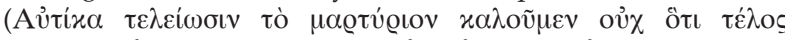

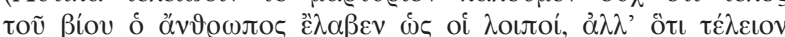

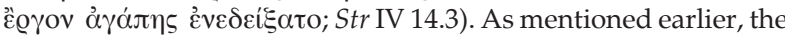
end of martyrdom is no other than the love for God and for the neighbour' (Str VII 42-55).

The influence of the martyr went beyond the celebration of triumph over tragic death. It also created and affirmed a particular Christian identity in the face of persecution, which was a witness to society. Justin affirms that the martyrs' courage strongly influenced his conversion (2 Apol 12), although Sanders (2000:171-172) does not think that it had such a strong bearing throughout the Empire. However, martyrdom was in danger of becoming trivialised, as it was covered by layers of folkloric belief. Some fervent disciples soaked their clothes in the blood of the martyrs' sacrifice, as such blood was believed to possess both healing and protective powers. Their remains were held in high esteem, with the stories of such relics becoming tokens of respectability for the newly built temples.

A quick historical review shows that the first centuries of the Christian era combined periods of relative peace with others of state-wide persecution of Christ-followers, especially at the beginning of the third century AD (Clark 2004:49-50). Although it is impossible to ascertain the number of casualties involved, what we know is that those who had 'confessed' the faith had to coexist with the lapsi (those who had succumbed to pressure to offer sacrifices to the emperor) in the community of the church. What separated the two groups of believers, in principle, was the willingness of the members of one group to suffer for the sake of the Name.

However, persecution did not end with the Christian movement, rather the blood of the martyrs was becoming the 'seed' (Latin semen), only strengthened it. "12 "Galerius, by 311 AD, had issued

12.According to Roman medical theory, 'the male seed that begets new life is made of refined blood' (Clark 2004:43). 
a decree, in terms of which Christians were allowed to 'exist again' and to rebuild their torn-down temples. There was, from then on, no need for Christians, apart from those missionaries who worked in dangerous places, to witness to Christ with the sacrifice of their own life. The image of the martyr then became even more important than it had been before.

\section{Ways of actualising martyrdom}

As with any religious and sociological phenomenon, martyrdom made both a lasting impact in the church, and became a token of pride and abuse. Worse yet, in some cases it was trivialised and became void of its original purpose. Thus, Gregory the Great (in the sixth century AD) equated 'carrying on one's cross' with the faithful observance of the holy days (Clark 2004:58). Once persecution had ceased, Christians were to recall the powerful symbol of the martyr in such alternate ways as are alluded to below.

\section{The monastic tradition}

The wilful renunciation of societal values that was found in the ascetic life during the third century AD onwards provided a sort of 'internal martyrdom' or 'long/white martyrdom'. Such martyrdom was perhaps a reaction to a Church which was becoming increasingly established and hierarchical, as well as to a society that failed to meet the needs of many. Such a reaction took the form of a life of self-renunciation, which eventually influenced society. Earlier, Tertullian, writing at the climax of the anti-Montanist polemic, had become a fervent defender of a radical Christian lifestyle that was coherent with Christ's way, and open to the Spirit's influence. Although Perpetua's martyrdom in AD 203 in Carthage had had a significant impact on the Church, Tertullian (a well-off citizen of the same city) and his group failed to receive much attention from the local authorities, in spite of their strong vocalisation of the Christian faith. As the importance of martyrdom was underplayed, Tertullian had to look elsewhere in search of criteria for his New Prophecy, which could be applied to those who no longer aspired to end their accommodated lives in the way in which Perpetua had done (Brown 1993:115-116). His answer was simple and profound: sexual continence, which consisted of the renunciation of any future sexual activity in the light of the grace of the Spirit. "Through continence you will acquire a great provision of holiness. With what you save in the flesh you can invest in the Spirit' (Tertullian, De exhortatione castitatis 10.1-2). Tertullian advocated a life of austerity, although such a life needed not to be lived in isolation from society. Although his teachings were conservative, his call, both to sexual renunciation and to a life of austerity, became theological topoi (Clark 2004:76).

The Life of Antony, which was written by Athanasius, describes the life of an accommodated man who ventured into the desert at the beginning of the fourth century, in response to his coming to understand the words of Matthew 19:21 as a personal appeal (Vit Ant 2-7). In the desert, Antony shared the company of others who had had similar experiences (3.2). The Life of Antony witnesses to a pattern of behaviour that became practised quite extensively, especially in the Egyptian desert. Such practitioners made themselves available to visits by the neighbouring peoples, who sought out the advice of the former, which was no longer available from the established church or society. Lives such as those of Antony had a remarkable impact on the people of the time. ${ }^{13}$

The reasons for choosing to withdraw from public life have been researched in a number of ways (cf. Clark 2004:66-70). Our chief concern in this regard is linking such a phenomenon to a form of martyrdom (whether it be labelled anachoresis, eremitism, askesis, monasticism, or the like). The Life of Antony provides an excellent example of such a linkage. Some Christians, who had

13.Athanasius was more interested in providing a 'model of ascetic life' (Castillo 2003:49) than in recording the details of Antony's life as such. been arrested in Egypt, were taken to Alexandria to be judged. When the news of such pending judgment reached Antony and his fellow monks, they emerged from their cells in the desert in order to aid their brothers and to spend time with them, as they waited in prison to be executed. The passion and zeal of the monks was such that the judge ordered that they should not be allowed to attend the court cases concerned. Antony, who 'desired to become a martyr but did not want to give himself in' (46.2; for he was aware that it was wrong to do so), disobeyed the judge's orders and appeared at the tribunal the next morning. The judge chose to ignore the monk's action and, once the persecution had ceased, Antony returned to his desert cell,

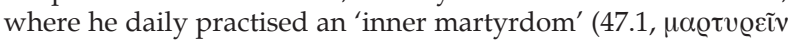

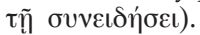

\section{The consecrated life}

In Roman Catholic tradition, the 'consecrated life' is understood as an actualisation of martyrdom once the persecutions had ceased (Uríbarri Bilboa 2002:157). Such a concept refers to the same 'extreme' which is reached during the paschal mystery, in the form of the mystery of love, which is manifested in the Lord Jesus (:160-161). ${ }^{14}$ The consecrated life embodied, in concrete terms, the fuga mundi (Castillo 2003:29-30). Castillo perceives several reasons for such 'fleeing', among them being the fact that the Church had experienced a rapid growth in numbers, which had tended to dilute her focus. Shallowness of approach and an ill-placed focus on the cult of personality then crept in quickly, ${ }^{15}$ resulting in an urgent need to return to the true message of the Gospel (Castillo 2003:33).

The theology of the consecrated life satisfies these two facets. On the one hand, such a life aims to function as a symbol of God's kenotic love, as happened in Jesus' life. On the other, such a life is aimed at imitating his life, in keeping with his form of kenotic love. Such is the folly of love, which can only be understood and desired from such a loving point of view. This embodiment of love occurred in the early Church, according to Uríbarri Bilbao, during which period 'every Christian desired the crown of martyrdom' (Uríbarri Bilbao 2002:154) ${ }^{16}$.

\section{The cruciform life}

The Protestant tradition, with its emphasis on the universal priesthood of believers, perceives martyrdom (if at all) in terms of the logic of the cross. Heavily influenced by Paul's theology, it stresses the cruciform life as a way of displaying the total consecration of the individual believer to the worship of God. What is lacking in outer symbolism (in terms of consecration, vows, and continence) is gained through a strong ideological emphasis, which sometimes tends toward taking the form of a rather amorphous manifesto of goodwill. Such conceptualisation is what Bonhoeffer (1995:43) termed 'cheap grace', namely grace without cost. The language of martyrdom has long lost its appeal in Protestant circles, preventing any possibility of the use of reward language. Perhaps, for such reasons, it seems as though the period of history under review belongs to a past era from which we have nothing, or little, to learn. However, in spite of some recent 'success/prosperity theologies', there is a widening sensitisation to the problem of suffering and Christ-

14.For Uribarri Bilbao, the consecrated life is a continuation of the kenotic form of love (Phlp 2:5-8), as well as of the 'grain of wheat' which, in order to yield fruit, has first to die (Jn 12:24).

15.For example, Cyprian of Carthage, the 'African Pope', describes his conversion and baptism without mentioning the following terms: Jesus; Christ; Christian community; gospel; or kingdom of God (Epist XXIII and XXXVI).

16.My aim is not to assess such, and other, perspectives in depth. Despite the possibility of our being critical of some historical projections, we know that the thousands of Christians who ventured into the desert from the second to fourth centuries lacked a pre-established plan and were inadequately organised to become what we might term clergy today. They merely sought solitude in which to find their true selves and in which they might be more faithful to the authentic the authentic gospel message. Such a factor is important. Other religions and peoples practised the same form of soltude seeking. What is novel in this regard is the emphasis on fidelity to the message of the gospel, rather than in the form that such behaviour eventually took. 
identification which does not renounce the former problem as if it had simply to do with the moral standard of the individual believer.

\section{CONCLUSION}

Whether we can benefit in our present context from the experience of the early Christians is open to comment. Firstly, martyrdom is neither an abstraction nor a mere theological topos, but the real fate of many in the faith, having 'a human face'.

Early Christians understood suffering as the locus of divine love. In contemporary society, 'suffering' is to be avoided at all costs, signalling the absence of an absolute Good. If our society strives after a life that is marked by stability and success, the early Christians, by means of the act of martyrdom, witnessed to the fact that suffering and pain could be transformed into a means of experiencing deeply moving encounters with God (Uríbarri 2002:163).

Accordingly, martyrdom 'with a human face' becomes a permanent warning for a complacent church in the midst of an affluent society. Suffering for Christ's sake becomes a possibility, being a shared gift that is available to Christians in all seasons and in any place (Phlp 1:29). The faith of the martyrs informs today's church that the love of God is more important than are our own lives.

Secondly, the experience of martyrdom invites the church to a fresh reading of Scripture. A mere 'ideological' reading of Scripture is a shortcut to the Christian life in comparison with 'martyrdom with a human face'. The latter invites the faithful to take into account both our social context and the implications that Christian discipleship holds for our lives. Once the martyrs' face is forgotten, our comprehension of Scripture becomes something less than a dynamic and spiritual exercise. The suffering experience of the early Christians defies opting for an easy way out for the Christian life.

Finally, the experience of martyrdom is a reminder that human beings cannot create the necessary conditions by means of which to earn God's grace. The martyr's temptation to present such an act as meritorious before God serves but to trivialise the concept of divine grace. Martyrdom, according to God's love, is a gift of the Spirit, who enables the individual to live out an experience of total surrender to the divine will. Rather than presenting a romantic or an out-of-the-world view of the martyr, the church would do well to find how she can spend herself on behalf of others in practical and concrete ways. Love for God and one's neighbour should be the only motivation for such martyrdom.

If martyrdom is understood as a genuine and sincere way of loving God, the task remains for the church to seek ways in which to resist and confront the powers of the age, similarly to how early Christ-followers did. During the first centuries of the Christian movement, Christ-followers were able to combat external criticism only by means of the exemplary lives that they led. Some were driven to die for the Cause. If 'the blood of the Christians is seed' (semen est sanguis Christianorum), we have to ask ourselves, as a church ready to witness to a loving God, where that 'seed' 'is nowadays.

Perhaps it is time to realise once more that, rather than a magic formula, the answer lies in the injunction: love God above everything else.

\section{REFERENCES}

Atanasio, 1995, Vida de Antonio: [Athanasius: Life of Antony] Introducción, traducción y notas de P. Rupérez Granados, (BP 27), Ciudad Nueva, Madrid.

Ayán Calvo, J.J., 1991, Ignacio de Antioquia, Policarpo de Esmirna, Carta de la Iglesia de Esmirna, (FP 1), Cuidad Nueva, Madrid.
Bloomquist, L.G., 1993, The function of suffering in Philippians, (JSNTSS 78), Sheffield Academic Press, Sheffield.

Bloomquist, L.G., 2007, 'Subverted by joy: Suffering and joy in Paul's Letter to the Philippians', Interpretation 61(3), 270-282.

Bonhoeffer, D., 1995, The cost of discipleship, transl. R.H. Fuller, Touchstone, New York.

Brown, P., 1993, El cuerpo y la sociedad: Los cristianos y la renuncia sexual [The body and society: Christians and sexual renunciation], transl. A.J. Desmont, Muchnik Editores, Barcelona.

Bultmann, R., 1910, Der Stil der paulinischen Predigt und die kynish-stoische Diatribe [The style of Paul's preaching and the Cynic-Stoic diatribe], (FRLANT 13), Göttingen.

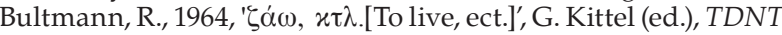
II, pp. 332-875, Eerdmans, Grand Rapids, MI.

Bultmann, R., 1976, Der zweite Brief an die Korinther [The Second Epistle to the Corinthians] (KEK), Göttingen.

Busto Saiz, J.R., 1998, El sufrimiento: ¿Roca del ateísmo o ámbito de la revelación divina? [Suffering: Stronghold of atheism of locus of divine revelation?], UPCO, Madrid.

Callahan, A.D., 1998, 'Dead Paul: The apostle as martyr in Philippi', in C. Bakirtzis \& H. Koester (eds.), Philippi at the time of Paul and after his death, pp. 67-84, Trinity Press International, Harrisburg.

Campbell, W.S., 2008, Paul and the creation of Christian identity, T \& T Clark, New York

Castelli, E.A., 2004, Martyrdom and memory: Early Christian culture making, Columbia University Press, New York.

Castillo, J.M., 1998, El seguimiento de Jesús, [Following Jesus] Sígueme, Salamanca.

Castillo, J.M., 2003, El futuro de la vida religiosa: De los orígenes a la crisis actual [The future of religous life. From its origins to today's crisis], Trotta, Madrid.

Clark, G., 2004, Christianity and Roman society, Cambridge University Press, Cambridge.

Cobb, L.S., 2008, Dying to be men: Gender and language in early Christian martyr texts, Columbia University Press, New York.

Craigie, P.C., 1976, The Book of Deuteronomy, Eerdmans, Grand Rapids, MI.

Dodds, E.R., 1965, Pagan and Christian in an age of anxiety, Cambridge University Press, Cambridge.

Driver, S.R., 1902, Deuteronomy, (ICC5), T\&T Clark, Edinburgh.

Droge, A.J. \& Tabor, J.D., 1992, A noble death: Suicide and martyrdom among Christians and Jews in Antiquity, Harper Collins, San Francisco.

Dunn, J.D.G., 1988, Romans 1-8, (WBC 38A), Word Books, Dallas.

Fitzgerald, J.T., 1988, Cracks in an earthen vessel: An examination of the catalogues of hardships in the Corinthian correspondence, (SBLDS 99), Scholars Press, Atlanta.

Forbush, W.B. (ed.), 1926, Fox's Book of martyrs, Winston, Philadelphia.

Fox, R.L., 1987, Pagans and Christians, Viking, Harmondsworth.

Freeman, D.N. (ed.), 1992, Anchor Bible Dictionary, 6 vols, Anchor, New York.

Gager, J.G., 1975, Kingdom and community: The social world of early Christianity, Prentice-Hall, Englewood Cliffs, NJ.

Garrett, S.R., 1990, 'The God of this world and the affliction of Paul, 2 Cor. 4.1-12', in D.L. Balch (ed.), Greeks, Romans and Christians: F.S. for A. Malherbe, pp. 99-117, Fortress Press, Philadelphia.

Gil Arbiol, C.J., 2003, Los valores negados: Ensayo de exégesis socio-científica sobre la autoestigmatización en el movimiento de Jesús [The denied values: Social-scientific study on the self-stigmatisation in the Jesus movement], Verbo Divino, Estella.

Glancy, J.A., 2006, Slavery in Early Christianity, Fortress Press, Minneapolis.

Gnilka, J., 1976, Der Philipperbrief [The Philippians letter], (HTK), Herder, Freiburg.

Hafemann, S.J., 1993, 'Suffering', in G.F. Hawthorne, \& R.P. Martin (eds.), DPL, pp. 919-921. IVP, Downers Grove, pp. 919-921.

Hawthorne, G.F. \& Martin, R.P. (eds.), DPL, 1993, Dictionary of Paul and his interpreters, IVP, Downers Grove.

Hock, R.F., 1980, The social context of Paul's ministry: Tentmaking and apostleship, Fortress Press, Philadelphia. 
Hodgson, R., 1983, 'Paul the Apostle and first century tribulation lists', Zeitschrift für die neutestamentliche Wissenschaft und die Kunde der älteren Kirche 74(1-2), 59-80.

Holloway, P.A., 2001, 'Consolation in Philippians': Philosophical sources and rhetorical strategies, (SNTSMS 112), Cambridge University Press, Cambridge.

Huber, S., (trad.), 1945, Las actas del martirio de San Policarpo 2, en Las cartas de San Ignacio de Antioquia y de San Policarpo de Esmirna, [Acts of the martyrdom of Polycarp, in Letters of Ignatius of Antioch and Polycarp of Smyrna] Desclée de Brouwer, Buenos Aires.

Kittel, G. \& Friedrich, G. (eds.), 1964-1976, Theological dictionary of the New Testament, transl. G.W. Bromiley, 10 vols, Eerdmans, Grand Rapids, MI.

Kruse, C.G., 1993, 'Afflictions, trials, hardships' in G.F Hawthorne \& R.P. Martin, (eds.), DPL, pp. 18-20, IVP, Downers Grove, pp. 18-20.

Lenski, G.E. \& Lenski, J., 1987, Human Societies. An introduction to macrosociology, McGraw-Hill, Singapore.

Lesbaupin, I., 1983, La bienaventuranza de la persecución [The blessing of persecution], Aurora, Buenos Aires.

Lohfink, G., 1998, La iglesia que Jesús quería: Dimensión comunitaria de la fe Cristiana [Jesus and community: Social dimension of Christian faith], transl. V.A. Martínez de Lapera, Desclée de Brouwer, Bilbao.

Malherbe, A.J., 1968, 'The beasts at Ephesus', Journal of Biblical Literature 87(1), 71-80.

Malherbe, A.J., 1983, Social aspects of early Christianity, 2nd edn., Fortress Press, Philadelphia.

Martín, S., 1997, El silencio de Dios: Diario de un misionero Mártir [The silence of God: Journal of a martyr], Planeta, Barcelona.

Merino Rodríguez, M., 2003, Clemente de Alejandría: Stromata $I V-V$, (FP15), Ciudad Nueva, Madrid.

Nock, A.D., 1933, Conversion: The old and the new in religion from Alexander the Great to Augustine of Hippo, Oxford University Press, Oxford.

Riddle, D.W., 1931, The martyrs: A study in social control, Chicago University Press, Chicago.
Rives, J.B., 1999, 'The decree of Decius and the religion of the empire', Journal of Roman Studies 89, 135-154.

Robinson, J.A.T., 1976, Redating the New Testament, Westminster Press, Philadelphia.

Sanders, J.T., 2000, Charisma, converts, competitors: Societal and sociological factors in the success of Early Christianity, SCM Press, London.

Schmitz, O., 1924, Die Christusgemeinschaft des Paulus im Licht seines Genitivegebrauchs [Paul's relationship with Christ in light of the use of the genitive], Berstelmann, Gütersloh.

Silva, M., [1992] 2005, Philippians, 2nd edn., (BECNT), Baker Academic, Grand Rapids, MI.

Stark, R., 1997, The rise of Christianity: How the obscure, marginal Jesus movement became the dominant religious force in the Western world in a few centuries, Harper Collins, San Francisco.

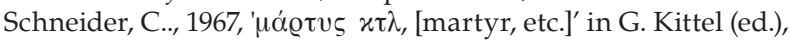
TDNT, pp. 474-514, Eerdmans, Grand Rapids, MI.

Tabor, J.D., 1992, 'Martyr, martyrdom', in D.N. Freeman (ed.), $A B D I V$, pp. 574-579, Anchor, New York.

Thompson, L.L., 2002, 'The martyrdom of Polycarp: Death in the roman games', Journal of Religion, 82(1), 27-52.

Uríbarri Bilbao, G., 2002, Portar las marcas de Jesús: Teología $y$ espiritualidad de la vida consagrada [Bearing the marks of Jesus. Theology and spirituality of the consecrated life], Desclée de Brouwer, Bilbao.

Weiner, E. \& Weiner, A., 1990, The martyr's conviction: A sociological analysis, Scholars Press, Atlanta.

Wengst, K., 1988, Humility: Solidarity of the humiliated, Fortress Press, Philadelphia.

Wilckens, U., 1992, La carta a los romanos [The letter to the Romans], vol. II., Rom 6-16, Sígueme, Salamanca.

Wilken, R.L., 2003, The Christians as the Romans saw them, 2nd edn., Yale University Press, London.

Windisch, H., 1934, Paulus und Christus [Paul and Christ], Hinrichs, Leipzig.

Yabén, H., 1990, Justino: Apologías [Justin Martyr: Apologies 1-2], Apostolado Mariano, Sevilla. 